\title{
Critical Analysis of Lecturer's Perception on Integrating Concepts of Sustainability in University Curricular
}

\author{
Anupama Gunawardana ${ }^{1}$, F.R. Arooz ${ }^{2}$, A. Peramunugamage ${ }^{3}$, R. U. Halwatura ${ }^{4}$ \\ ${ }^{1,2,3,4}$ Department of Civil Engineering, Faculty of Engineering, University of Moratuwa, Sri Lanka
}

\begin{tabular}{l}
\hline Article Info \\
\hline Article history: \\
Received Jul 3, 2020 \\
Revised Agu 7, 2020 \\
Accepted Sep 9, 2020 \\
\hline
\end{tabular}

Keywords:

Lecturer Perception

Sustainability Concept

Sustainability Development

University Curricula

University Education

\begin{abstract}
ABSTRAK
Purpose of the study: The growing emphasis on incorporating sustainability concepts in tertiary education has lead higher education institutions in developing countries to infuse sustainability content into their curricula. The wider purpose of this study is to promote the integration of sustainability concepts within Sri Lankan Universities. The study uncovers and presents the perception of university academics on integrating sustainability in higher education.
\end{abstract}

Methodology: An online-survey was carried out in the month of January, 2019 at the University of Moratuwa, Sri Lanka across four faculties; engineering, architecture, information and technology and business. A descriptive analysis was employed to present the perceptions of the respondents according to different faculties. The obtained data were analyzed using Microsoft excel.

Main Findings: Results revealed, $46.93 \%$ have already integrated sustainability concepts while $59.18 \%$ are willing to integrate in the near future. $80 \%$ have perceived that university curriculum should improve, according to the country's need while providing particular trainings. $60 \%$ felt that knowledge and skills in ICT should be developed and adequate human resources should be deployed prior to incorporate sustainability concepts.

Novelty/Originality of this study: analyzing the perception of university lecturers on incorporating sustainability concepts across the university curricular, has never conducted in a Sri Lankan university. This is manily conducted to identify the gaps pertaining on intergrating sustainability concepts across university curricular and to identify the barriers exciting for education for sustainable development in Sri Lankan context.

This is an open access article under the $\mathrm{CC} B Y-N C$ license

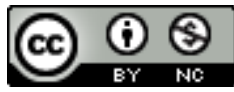

\section{Corresponding Author: \\ Anupama Gunawardana \\ Department of Civil Engineering, Faculty of Engineering, University of Moratuwa, Sri Lanka. University of Moratuwa, Bandaranayake mawatha, Katubedde, Sri Lanka \\ Email: anupamagunawardana77@gmail.com}

\section{INTRODUCTION}

In 1992 at the United Nations Conference on Environment and Development (UNCED)-Agenda 21, education, training and public awareness were identified as the three crucial tools for the transition of the society towards sustainable development (SD). In such a prevailing scenario, Education for sustainable development (ESD) was emerged as a concept which encourages the transformation of education to a level which can effectively contribute the reorientation of societies towards sustainable development [1]. In 2005, 
United Nations Decade of Education for Sustainable Development (DESD) was launched to begin a 10 years (2005-2014) commitment and global movement towards improving education systems towards SD and mobilizing the educational resources of the world to create a more sustainable future. Integrating the practices, principles and values of SD into all parts of education and learning was the overall goal of DSED so that these educational efforts encourage the behavior changes which lead to create a more sustainable future in terms of economic viability, environmental integrity and a just society for present and future generations [2].

According to UNESCO, ESD empowers learners to take informed decisions and responsible actions for environmental integrity, economic viability and a just society, for present and future generations, while respecting cultural diversity. Furthermore, it states that ESD is a holistic approach where the learning content should integrate key SD issues which comes under different themes such as climate change, disaster risk reduction, biodiversity, sustainable consumption and production into the teaching curriculum. Similarly, learning environments should be learner centered and interactive which explores actions that inspire learners to act for sustainability. Learning outcomes should promote key capabilities such as critical thinking, collaborative decision making and capturing responsibility for present and future generation. Ultimately, it accounts for societal transformation by uplifting skills for green jobs, allowing greener economies and societies and encouraging people for sustainable lifestyles [3].

According to final report of world conference on ESD, "Shaping the future we want" ESD can be applied in different levels of education in a wide range of settings such as schooling, vocational education, higher education, workplace training, adult learning and public awareness education. These levels differ according to three basic contexts of learning such as formal, non-formal and informal. Among these three basic contexts, highest priority is given to formal education which is based on recognized and developed curriculum and on accepted teaching and assessment methods which are mainly carried out in school, college and university systems [4].

In the avenues of formal education, higher educational institutes (HEI's) play a major role to achieve sustainability, economic opportunities as well as sustainable living which instill students to become responsible global citizens in both campus life as well as at societal levels [5]. At the start of the 21st century, a higher number of universities and HEI's are boarding ahead with adopting more responsible catering towards increasing sustainable development agenda [6]. Among the HEI's, universities are considered as major drivers for fostering attributes of sustainability and contributing sustainable development worldwide [7]. The importance of universities in promoting sustainable development have been indicated in several declarations such as Talloires Declaration in 1990, Agenda 21 in 1992, the Kyoto Declaration in 1993, Global Higher Education for Sustainability Partnership in 2000, the Luneburg Declaration in 2001, the Sapporo declaration in 2002, Graz Declaration in 2005, Abuja Declaration on Sustainable Development in Africa in 2009, the Rio+20 Higher Education Sustainability Initiative, as well as the UN Decade for Education for Sustainable Development [5, 8, 9].

Historically, universities have played an influential role in transforming societies, by educating decision makers, leaders, entrepreneurs and academics [10]. Therefore, integrating concepts of sustainability into university curricula create the platform for students to identify the interactions of environmental issues with social and economic avenues and ways of addressing these consequences as local and global citizens [7]. To enhance the aspects of sustainability, universities are capable of implementing numerous practical activities. According to UNESCO guidelines environmentally conscious universities are able to provide knowledge and concern for ecological interdependence, attitudes, values and skills required to protect and enhance the environment, and behaviors of individuals and society towards environment [11]. Universities have the possibility of incorporating aspects of sustainable development into their operations, curricula, research, and outreach as well as with internal and external stakeholders. These activities can encourage and help to build the interest of students to view sustainability in a holistic manner, to understand how their actions and decisions affect the environment and most importantly to promote sustainable concepts in their professional life [12].

When considering the world's scenario, various attempts have been undertaken to uplift the concept of ESD in the universities. New environment related degree programs have been introduced throughout the universities of the world. Wu and Shen have highlighted in their research how environment education (EE) has been incorporated to streams such as science, engineering and business [13]. Chuvieco, Burgui-Burgui, Da Silva, Hussein and Alkaabi have revealed that sustainability indicators are higher in students who follow environment related degrees than of other disciplines [14]. Similarly, there is an explicit difference in proenvironmental behavior and attitudes of the students who purchase environmental related degree programs [15]. Another prominent attempt is the introduction of sustainability related course modules to the university curricular systems. According to the research by Bielefeldt, the sustainability module which articulated with civil and environmental engineering triggered the performance of students towards 
sustainability [16]. Similarly, integrating case studies with traditional disciplines contribute students to better understand the conceptual aspects of sustainability and harness those concepts in practical applications within employment [17]. Embedding concepts of sustainability into exciting modules is another core methodology used within the university system. These incorporations should be done in a systematic way unless it might lead to reductions in the amount of core subject matter being taught [18].

University researchers have undertaken a new trend of incorporating sustainability aspects within their research criteria. Prime issues associated with sustainability are been highlighted and more concern is provided. Bakac has shown through his research how engineering students response to climate change through a perception scale developed after incorporating sustainability aspects with the curricular [19]. Researching in terms of sustainability indicators in another innovative technique which have been followed recently. Brito et al have indicated the use of sustainability indicators as reliable methodologies to access the progress of sustainable development [20]. Furthermore, some universities have adopted components of sustainability into their campus operations as initiatives of ESD. Abubakar, Al-shihri, \& Ahmed have explored that College of Architecture and Planning, University of Dammam, Saudi Arabia is moving towards sustainability by incorporating sustainability aspects into operations and practices such as garbage recycling, energy conservation, water conservation, landscaping, and transportation where the students can witness and experience the sustainability initiatives within the university settings [5].

However, the path of creating ESD is inconvenient because there are plenty of barriers which exist to integrate concepts of sustainability into university systems. Most of the universities around the world conduct degree programs in English language. Nevertheless, the students who enroll for these universities are more competent with their local languages rather than English language. Therefore, the lack of competency in English language is an accountable obstacle prevailing within the university system. Watkins \& Richters have revealed in their research how the less proficiency in English language have resulted the barrier of education for Karen refugee women in Australia [21]. Similarly, the poor knowledge and skills on information communication technology (ICT) of the students is another major barrier usually shown within the university system. A research conducted in Nigeria has revealed that lecturers' access and exposure to ICT resources in Nigeria is still low which has resulted poor university education management towards sustainable national development [22]. Apart from ICT, Kiangi has revealed how unequal access to internet facility and poor bandwidth have influenced university education in Nambia [23].

Furthermore, lack of proper technologies necessary for the practicals and for researching is a prominent barrier shown by most of the universities in developing countries. A research conducted in Africa has revealed that low comfort levels with technology and insufficient technical support have resulted failures in learning management system (LMS) in university education [24]. Most of the universities are lacking of proper academics and other human resources necessary for the proper management of university systems. Similarly, lack of training opportunities for students and teacher centered learning which require a major curricular reforms are some of the prominent barriers among the university education. A research conducted in Africa for a higher educational institute (HEI) which offered agriculture education and training (AET), proposed that restructuring of curricular and increasing training opportunities through mentoring programs are the best solutions for providing quality education in HEIs [25].

\subsection{Education for Sustainable Development In Local Context}

Sri Lanka is a South Asian lower middle income country with a GDP per capita of USD 4073 (2017) [26]. Sri Lanka is one of the countries which maintain highest literacy rates in South Asia where it recognizes education as a key factor to upgrade the economic level of the country. Sri Lankan education system is mainly divided into three major categories such as elementary education, secondary education and higher education. Elementary education usually starts at grade 1 at the age of 5+ and ends in grade 5 at the age of 9+. Secondary education begins from grade 6 which culminates at grade 11 after facing General Certificate of Education Ordinary Level (GCE O/L). Students who pass the GCE A/L examinations can proceed to collegiate level which is also known as GCE A/L. According to the records of Ministry of higher education in year 2013, about $60 \%$ are eligible to enter collegiate level. GCE A/L examination is the prerequisite to enter the Higher education in Sri Lanka [27].

Higher education is mainly the university education in Sri Lanka and university entrance process is highly competitive in Sri Lankan context. According to University Grants Commission (UGC) out of $60 \%$ of the students who pass the GCE A/L only $17 \%$ of students are eligible to enter the university. Students are ranked and admitted to universities according to the standard scoring system based on their A/L examination results. The functions of the University education is coordinated and planned by UGC and in Sri Lanka, UGC is under the authority of ministry of Higher Education [28]. There are 15 government universities under the authority of UGC and according to the university statistics 2017, a total of 30, 662 students were enrolled for undergraduate courses for year 2017 [29]. Similarly, in year 2017, total graduate output (bachelor degree) is 
26, 015 [30]. These graduates join with both private and government sector for occupations after the completion of degree. Therefore it is evident that graduates, have a higher contribution on improving the social, economic and environmental standards of the country.

Being a developing country, Sri Lanka has also identified sustainable development as an effective forefront. The consequences of rapid and high density urban sprawl experienced by Sri Lanka leads to high demand for shelter, energy and means of livelihood. These scenarios requests for sustainable urban development that would improve energy efficiency, waste reduction which ensures intergenerational equity and diminishes environmental pollution, resource depletion and eco system degradation [5]. Therefore, sustainable development has become a crucial concept for a developing country like Sri Lanka, to overcome activities such as over-population, resource over consumption, environmental degradation and to improve the quality of this generation as well as future generations [12]. The youth population of Sri Lanka is 4.4 million which is of $23 \%$ [31] of the entire population of the country. In order to achieve sustainable development in the country, it is very important challenge for the young generation to identify the social, economic and cultural dimensions of the environment and in the process of acquiring a sustainable future, the necessary of more skilled individuals is crucial [7]. Integrating ESD across the university education system and providing learning opportunities will allow youth to better equip with the knowledge, skills and practices imperative to deal with sustainable development in all aspects [5]. Similarly, incorporating sustainability concepts with university curricular encourage and help to build the interest of students to view sustainability in a holistic manner, to understand how their actions and decisions affect the environment and most importantly to promote sustainable concepts in their professional life [12]

\subsection{Problem Statement}

In order to initiate ESD in the university education system in Sri Lanka, it is crucial to identify the current status of ESD at local context in university system. Among the academic settings, lecturers are the most significant group of people whom can centrally involve in developing concepts, content, pedagogy, evaluation and research with respect to sustainable development [5]. They can educate students to find clarifications for unsustainable living while embedding sustainability concepts for teaching and researching in their education system. Similarly, university students mainly deal with lecturers and they have a strong capability to influence student's perception [6]. Therefore, determining lecturers perception on ESD is very much imperative and it is thought to be the very first step for incorporating sustainability concepts with university education system in a developing country like Sri Lanka. Furthermore, the results gained from such a study can strongly influence to construct an explicit backbone for ESD in university system in long term. Therefore, this research study was conducted to investigate the following objectives,

1. To identify the barriers existing for ESD in university education system.

2. To determine the perception of university lecturers on integrating concepts of sustainability into the university curricula system.

3. To identify the extent to which lecturers have incorporated concepts of sustainability in their teaching modules.

\section{RESEARCH METHOD}

The study was implemented at university of Moratuwa (UoM) which is located at Moratuwa, in the western province of Sri Lanka. The origin of the university is dated back to 1893 as Government Technical School (GTS) during the British rule nevertheless, it was established as UoM on 22nd of December 1978 under the Universities Act No.16 of 1978 and operates under the authority of UGC. UoM is a state university which is predominantly a Technology university and the most competitive university for the Engineering students. University has fourteen (14) undergraduate degree programs distributed in four (4) faculties; faculty of engineering, faculty of architecture, faculty of information technology and faculty of business and by 2017 it had an undergraduate student population of seven thousand six hundred eighty seven (7687) distributed among all four faculties. University has fifty six (56) postgraduate degrees at MSc, MPhil and PhD levels where the activities of postgraduates are coordinated by Faculty of Graduate Studies. University has an academic staff of Four hundred fifteen (415) distributed among twenty (20) departments. According to the tracer survey done in $2017,92.6 \%$ of all graduates and $96.6 \%$ of the engineering graduates were reported to be employed by the time of convocation and these results confirm their immense contribution in the task of developing the nation [32]. According to the Accreditation Board for Engineering and Technology, all engineers should be very much familiar with the concepts of sustainability and "The Engineer of 2020" report (National academy of engineering, 2004) notes the significance of sustainability in the toolbox of engineers [16]. The graduates who are passing out from a technology university have more possibilities of 
contributing to sustainable development of the country in vivid aspects. Therefore, it is evident that UoM is the most suitable university to implement the study at Sri Lankan context.

Online questionnaire survey was designed and distributed among the academic staff of all faculties of UoM. Questionnaire consisted of twelve (12) questions which included likert scale questions, open ended and close ended questions. First two questions were included to identify the basic demographic information of the respondents such as designation and the main research area.

As mentioned in the literature review, from the studies conducted in different countries, some barriers existing for ESD have been identified. In order to identify whether those barriers exist in Sri Lankan context as well, barriers were given as gaps and respondents were asked to rate those gaps according to their perception. Here a likert scale of 5 points ranging from strongly agree to strongly disagree was provided to rate the gaps. Gaps included poor knowledge and skills on ICT, lack of fluency in English language, unequal access for internet, poor bandwidth, and curriculum reforms to match the country need, in adequate training opportunities, lack of human resources and lack of technologies. The next set of questions were provided to identify the perception of lecturers on integrating sustainability concepts in university curricular system. In order to categorize the results according to faculties, fourth and fifth questions were represented faculty and the department. Sixth question of this set was a close ended question and it was to identify whether respondent has already integrated concepts of sustainability in their curricula programs. The seventh question was a close ended question which is inter linked with the third question where if the answer in the sixth question was yes, respondents were given 3 choices to select at which level they have integrated. Three choices include the educational levels such as $\mathrm{BSc}, \mathrm{MSc}$ and $\mathrm{PhD}$. Eighth and ninth questions were descriptive questions which are consistent with the sixth question where it implies the subject levels and topic levels in which the respondents have already integrated these concepts in their teaching curriculums.

The tenth question of this set, was a close ended question which denotes, whether the respondents are planning to include concepts of sustainability in their future curricular programs. The eleventh question was included to explore the respondent's perception on importance of integrating sustainability concepts in university curricula programs. Likert scale ranging from 1 to 5 attributed from strongly agree to strongly disagree was provided. The final question of the set was an open ended question which was included to get the suggestions in terms of knowledge, technology and information required for integrating concepts of sustainability in curricula programs. Respondents were allowed to provide descriptive answers based on their perception. The format of the questionnaire is given below.

1. Designation

2. Main Research Area

3. How would you rate for following barriers existing for ESD in higher education? (Rate as strongly agree to strongly disagree)

i. Lack of fluency in English language

ii. Poor knowledge and skills on ICT

iii. Unequal access for Internet

iv. Poor bandwidth

v. Curriculum reforms to match the country need

vi. In adequate training opportunities

vii. Lack of human resources

4. Faculty

viii. Lack of technologies

5. Department

6. Have you integrated sustainability concepts in your teaching modules?

7. If "YES" in which level? Bachelor, Masters, PhD

8. In which subject level - please indicate subjects

9. In which topic level - please indicate subject and topics

10. Are you planning to integrate sustainability concepts in your future curricular program?

11. How would you rate importance of integrating sustainability Concepts University curricular? (Rate as strongly agree to strongly disagree according to your perception)

12. What Information/Knowledge/Technology is required for integrating sustainability concepts in university curricular?

\section{RESULTS AND DISCUSSION}


The survey which was distributed among all academic staff members (415) of UoM, 49 members which is of more than $10 \%$ of total academic population have responded to the questionnaire survey. The obtained data were analyzed using Microsoft excel. The analyzed results of the first question is given in figure 01. According to the results, highest respondents are from senior lecture category which is of $68 \%$. Senior professor is the category which included the least respondents with $02 \%$.

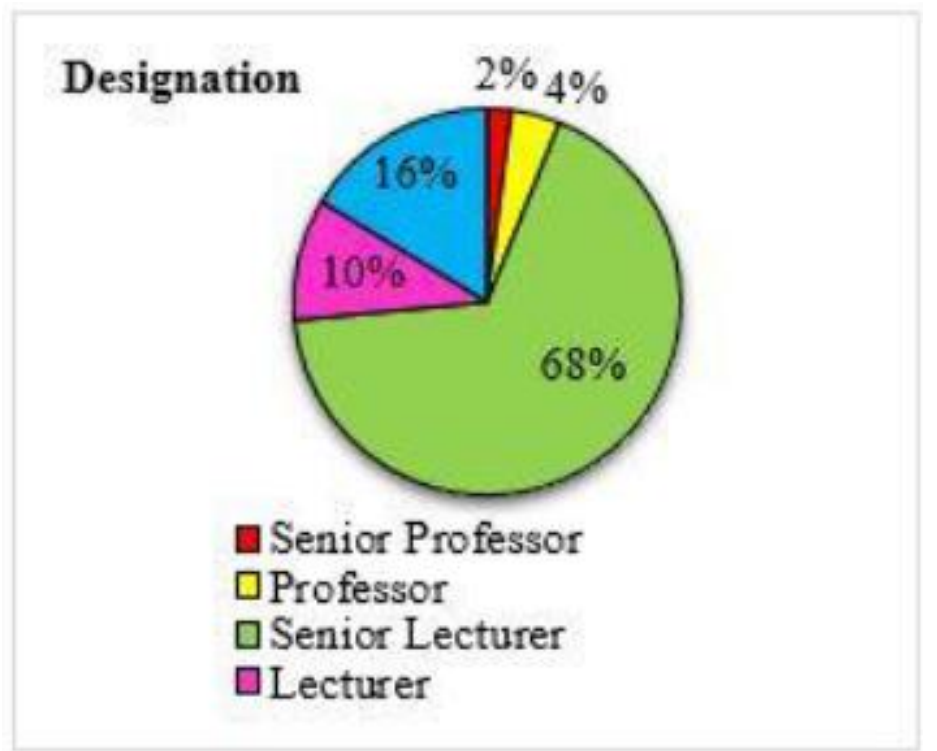

Figure 1. Distribution of Respondents according to their designation

According to the results of the second question, it was identified that the respondents were distributed among diverse research fields. Computer Engineering, Spatial Planning, Robotics and Automation, Maritime transport, Business Process Management, Fashion Design, Multimedia information retrieval and data mining were some of them. However, some of the respondents have already focused their research fields to sustainable educational concepts. Among those, research areas such as low energy architecture, sustainable material and design, net zero emission building operations, waste management, plastic recycling and clean technology were prominent.

The results of the third question, the analysis of gaps pertaining for ESD in higher education is given in Figure 2. According to Figure 2 (a), more than 53\% of the respondents agree with that the lack of fluency in English language is a barrier for ESD in higher education at Sri Lankan context. In UoM all the lectures are conducted in English language thus all the students are not equally competent in it. The main reason for this is that students learn their school curricular in local languages such as Sinhalese or Tamil in Sri Lanka. When comes to tertiary level which is also known as Advanced level education in Schools, most of the students give less priority to English language because in more priority should be given to subject matters rather than developing language competencies. Students who enroll universities with such a background are incapable of grabbing the curricular taught in English language. Their thinking capacity reduces and fail to answer properly during the exams because they haven't grasp the major concepts in the subject matter. Therefore, prime importance should be given in enhancing the English language competency of the students. Universities have already implemented various strategies at different levels. Universities conduct English language classes during orientation programs. There are various students clubs and associations where students can join and develop their English language competency. In the meantime, government and necessary authorities should take needed precautions to develop English language skills in long term.

According to the results of Figure 2 (b), more than $67 \%$ agree with that the poor knowledge and skills on ICT is a barrier for ESD in higher education in Sri Lanka. Similarly, according to Figure 2 (c) almost 50\% agree with unequal access for internet and according to Figure 2 (d) more than $36 \%$ agree with the poor bandwidth as barriers for ESD in higher education in Sri Lanka. Issues related to ICT is a common consequence in developing countries. Inequity, poor access to digital infrastructures and lack of other resources are main obstacles in this regard. Students who come from remote areas are lacking ICT skills and computer literacy. Therefore, students who come from such a background, experience various difficulties. Searching for extra learning materials, dealing with soft wares, accessing to campus Moodle system are some of those. These consequences eventually lead to the failure of ESD. Similarly, these ICT related issues are main barriers for student centered learning process [33]. Therefore, government and necessary authorities 
should implement digital infrastructures and other required resources equally throughout the country. Similarly, necessary actions should be taken to improve knowledge on ICT from the school education.

According to Figure 2 (e), more than $83 \%$ have felt the need of the curricular reforms to match the country need. Figure 2 (f) confirms that almost $90 \%$ seek for adequate training opportunities and Figure 2 (g) implies that almost $70 \%$ agree with the barrier, lack of human resources for ESD in higher education. According to Figure 2 (h), more than 57\% agree with the lack of technologies for ESD in higher education. The teaching curricular should be improved and updated along with the technical pedagogy in order to match the national goals. Initiating online education as a solution for increasing student population is another implementation. Including sustainability concepts to the teaching curricular is crucial and a timely need. In order to provide necessary training opportunities, universities should enhance the collaboration with the private sector and industries. Not only the students, but also the academic and nonacademic staff should be enriched with a proper training. In terms of sustainability, real case studies should be included along with these training programs. Site visits should be included to showcase live initiatives of sustainability. These actions will improve the skills, values as well as the attitudes of the students regarding sustainable development. Similarly, adequate training opportunities can reduce the unemployment rates of the graduates and will develop the future entrepreneurs [34]. Well trained academic and nonacademic staff should be provided to all universities and fill the void of lack of human resources in universities. Proper intakes should be done by the necessary authorities and at the same time, other resources should be provided. Lack of proper technologies in also a crucial obstacle for ESD in higher education. Most of the universities in de veloping countries do not have upgraded technological facilities. When the students conduct researches with the limited technological facilities, those are quickly become outdated and students might have to face difficulties during the practical sessions due to the lack of technologies. Therefore, government and necessary authorities should equip universities with proper technological facilities and this can ultimately enhance ESD in higher education. Therefore, these barriers should be addressed at qualitative level in order to achieve the policy objective of sustainable development and to make it fully operational [35].

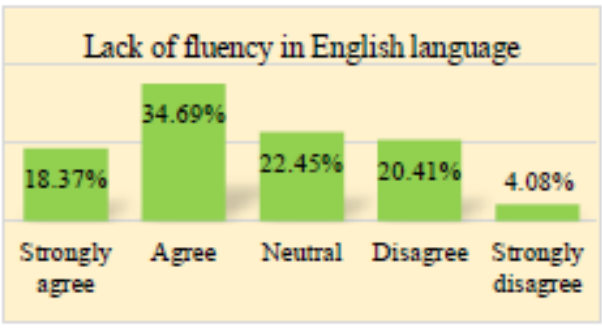

Figure 2 (a)

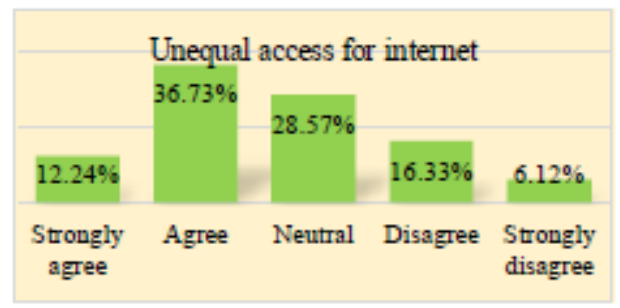

Figure 2 (c)

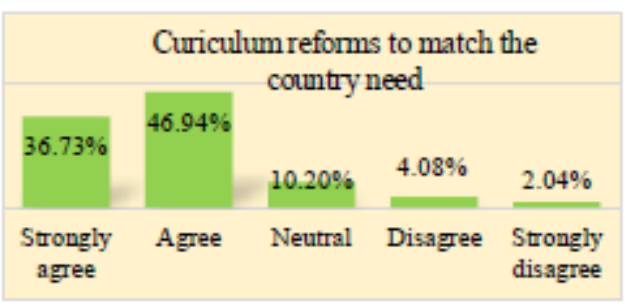

Figure 2 (e)

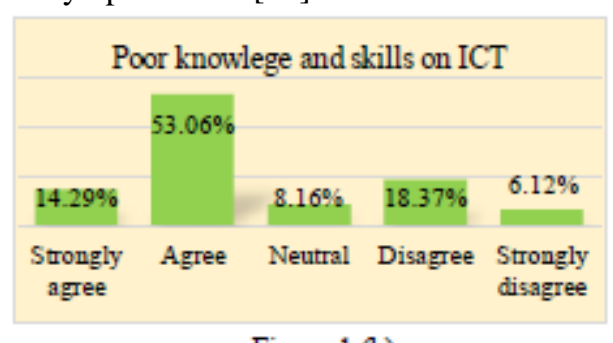

Figure 1 (b)

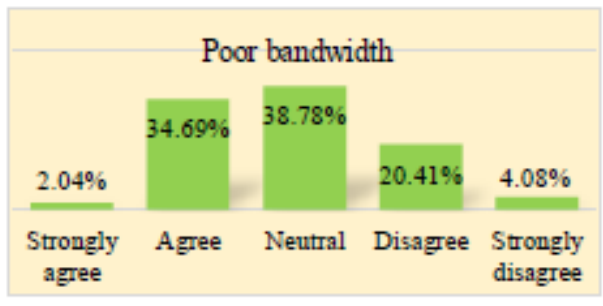

Figure 2 (d)

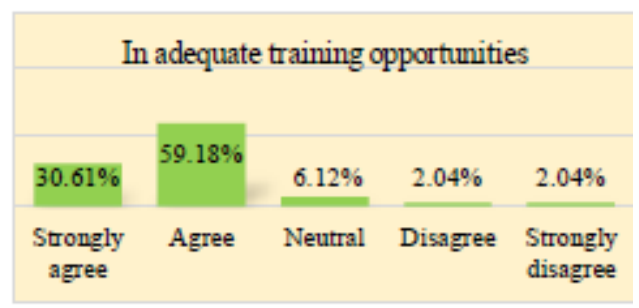

Figure 2 (f) 


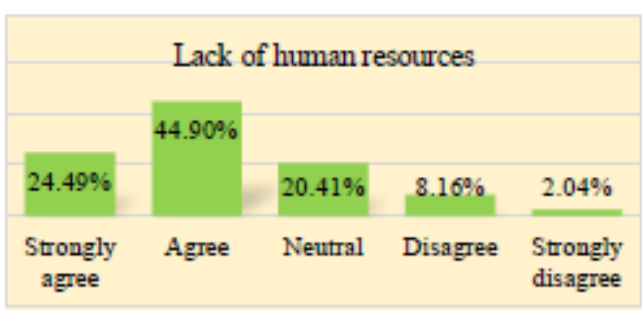

Figure 2 (g)

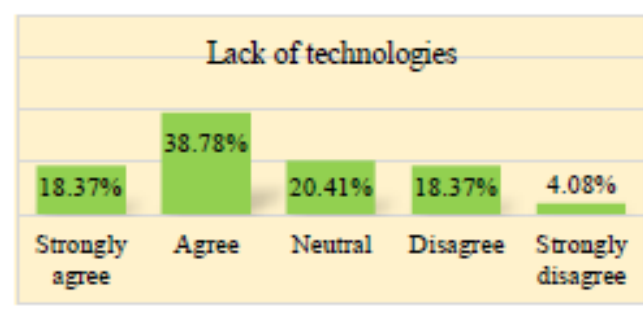

Figure 2 (h)

The analyzed results of the fourth and fifth questions are given in the Table 1.According to results, majority of the respondents are from Engineering faculty. Equal number of lecturers have responded from other three faculties.

\begin{tabular}{|c|c|c|c|c|c|}
\hline Faculty & $\begin{array}{l}\text { No: of } \\
\text { respondents }\end{array}$ & $\begin{array}{l}\text { No: of } \\
\text { respondents as } \\
\text { a percentage } \\
\% \text { from all } \\
\text { faculties }\end{array}$ & $\begin{array}{l}\text { Representative } \\
\text { departments }\end{array}$ & $\begin{array}{l}\text { No: of } \\
\text { respondents }\end{array}$ & $\begin{array}{l}\text { No: of } \\
\text { respondents as } \\
\text { a percentage } \\
\text { within the } \\
\text { fac }(\%)\end{array}$ \\
\hline \multirow[t]{4}{*}{ Architecture } & 8 & $16.32 \%$ & Architecture & 3 & $37.5 \%$ \\
\hline & & & $\begin{array}{l}\text { Town \& country } \\
\text { planning }\end{array}$ & 3 & $37.5 \%$ \\
\hline & & & Building economics & 1 & $12.5 \%$ \\
\hline & & & Integrated design & 1 & $12.5 \%$ \\
\hline \multirow[t]{9}{*}{ Engineering } & 25 & $51.02 \%$ & $\begin{array}{l}\text { Textile and clothing } \\
\text { technology }\end{array}$ & 8 & $32 \%$ \\
\hline & & & Mechanical engineering & & $16 \%$ \\
\hline & & & $\begin{array}{l}\text { Transport and logistics } \\
\text { management }\end{array}$ & & $12 \%$ \\
\hline & & & Civil engineering & & $8 \%$ \\
\hline & & & $\begin{array}{l}\text { Material science and } \\
\text { engineering }\end{array}$ & & $8 \%$ \\
\hline & & & Electrical engineering & & $8 \%$ \\
\hline & & & $\begin{array}{l}\text { computer science and } \\
\text { engineering }\end{array}$ & & $4 \%$ \\
\hline & & & $\begin{array}{l}\text { earth resource } \\
\text { engineering }\end{array}$ & & $4 \%$ \\
\hline & & & $\begin{array}{l}\text { electronic and } \\
\text { telecommunication } \\
\text { engineering }\end{array}$ & & $4 \%$ \\
\hline Information & 8 & $16.32 \%$ & Information technology & 5 & $62.5 \%$ \\
\hline \multirow{2}{*}{ Technology } & & & Interdisciplinary studies & 2 & $25 \%$ \\
\hline & & & $\begin{array}{l}\text { Computational } \\
\text { mathematics }\end{array}$ & 1 & $12.5 \%$ \\
\hline \multirow[t]{2}{*}{ Business } & 8 & $16.32 \%$ & $\begin{array}{l}\text { Management of } \\
\text { technology }\end{array}$ & 5 & $62.5 \%$ \\
\hline & & & Industrial management & 3 & $32.5 \%$ \\
\hline
\end{tabular}

The analyzed results of the sixth question is given in Figure 03. According to the results it is clear though all respondents have not integrated sustainability concepts in their teaching curricular, all faculties have already integrated sustainability concepts in their teaching curricular. In every faculty, there is a considerable percentage that have not integrated sustainability concepts in their teaching curricular. The reasons for these variations can be either their teaching curricular are more technical therefore, most attention has given to technical pedagogy. Some respondents may still have not identified the necessity of these concepts therefore, they might have not integrated these concepts in their teaching curricular. The analyzed results of the seventh question is given in the Table 02. According to the results, majority of the respondents have integrated these concepts at Bachelor teaching curricular. When consider the postgraduate levels, 
Architecture and Engineering faculties have moved up to $\mathrm{PhD}$ level while IT and Business faculties have integrated up to Masters level.

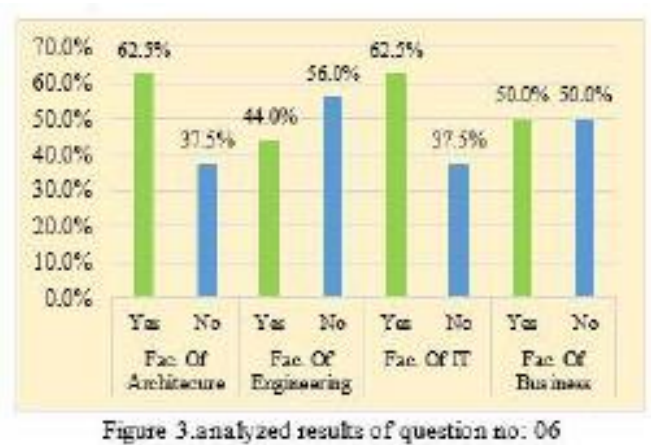

Table 2. Analyzed results of question no: 07-Relative percentage of integration at different educational levels

\begin{tabular}{llll}
\hline \multirow{2}{*}{ Faculty } & \multicolumn{3}{l}{ Percentage of integration at different educational Levels } \\
\cline { 2 - 4 } & Bachelors & Masters & PhD \\
\hline Architecture & $40 \%$ & $20 \%$ & $40 \%$ \\
Engineering & $56.25 \%$ & $37.5 \%$ & $6.25 \%$ \\
Business & $66.6 \%$ & $33.4 \%$ & $0 \%$ \\
IT & $60 \%$ & $40 \%$ & $0 \%$ \\
\hline
\end{tabular}

The results of the eighth and ninth questions were categorized based on faculties. Faculty of Architecture- Ones who have integrated, have used it in subjects; low energy architecture, climate and comfort, net zero emission buildings, environmental economics, solar geometry and land use optimization under different topic levels such as environmental sustainable design, transportation planning, infrastructure planning, regional and local projects and developing a land use optimization model for salt water intrusion area. Majority of the respondents were from Architecture department and Town and Country Planning department. By examine the subjects it is clear that these subjects are more consistent with the areas of these departments. It is a matter of appreciation that they have recognized the necessity of these concepts to a developing country like Sri Lanka and have already integrated in their teaching curricular.

Faculty of Engineering- With the results it is observed that ones who have integrated, have used it in subjects; energy management systems, building automation systems, energy technology and environment, energy conservation, clean technology and sustainability, industrial engineering, industrial product development, maritime transport, transport economics, fashion and textile, optical and electronic device engineering and global fashion business. Also they have further categorized into topic levels such as building energy management systems, sustainable design and development, carbon footprint, green technology, biogas systems, bunker fuel usage, containment of externalities in transport sector, solar cells, impact of climate change across fashion supply chain and consumer knowledge, awareness, their purchase intention and preferences towards sustainable fashion, slow fashion, up-cycling garments, natural dyes, zero wastage garment manufacturing, zero wastage consumer life style, eco fashion, sustainable fashion and textiles. Most of the subjects and topics relevant to this section are from fashion designing sector because majority of the respondents in the engineering faculty were from department of textile engineering. Observing these subjects and topics, most of the subjects are relevant to environment sustainability aspects. However, Charu has contented through her research that for decision making sensitive to sustainable issues, engineering students need to be equipped with wider horizon on concepts in terms of economic, environmental and social attributes distributed among diverse field of subjects [36]. Therefore, equal concern should be given for all three dimensions of sustainability when preparing teaching curricular.

Faculty of Business- Respondents who have integrated, have used it in subjects; technology management, marketing and management under different topic levels such as CSR and green marketing, sustainability marketing, business strategy, and innovation management. The graduate output of this faculty will mostly join the workforce as skilled managers and businessmen of different sectors because in Sri Lanka, the demand for this sector is really high. However, Fisher and Bonn have concluded in their research that business sustainability can be strongly influenced by the knowledge and skills gained through subject matter [37]. By examine the subjects it is clear that they have mainly integrated concepts in the marketing fields. Therefore, it is much essential and a timely need to incorporate sustainability concepts in other aspects of business as well. 
Faculty of IT- With the results was observed that ones who have integrated, have used it in subjects; marketing and data mining under different topic levels such as green marketing, professional practice and applications relevant in association mining. It was revealed that information technology has a significant role in assisting organizations as well as various institutions to develop, implement, monitor and analyze sustainable practices in ideal manner [38]. Therefore, incorporating concepts of sustainability is much essential to enhance the knowledge and to upgrade the perception of the students in this study field. The analyzed results of the tenth question is given in the Figure 04. The majority of the output of architecture faculty is architects whom can directly linked with the construction industry of the country. Therefore, Architects have a high responsibility in promoting sustainable constructions. With the results, it is clear that majority of the lecturers in the faculty have identified the need of sustainability in their particular field and targeted incorporating in their relevant subject areas. Majority of the respondents been from textile and clothing technology might be the reason for the deviated results of engineering faculty. If the majority of the respondents were from Civil Engineering or mechanical Engineering with lots of sustainability applications this value would be fairly changed. Less of applications in the sustainability in IT field might be the reason for the results shown by IT faculty. A higher number of respondents from Business faculty are willing to integrate sustainability aspects in their future curricular. There are vivid areas in Business field where sustainability aspects to be incorporated. Therefore, determining these areas and incorporating aspects will be very much beneficial for Sustainable development of the country.

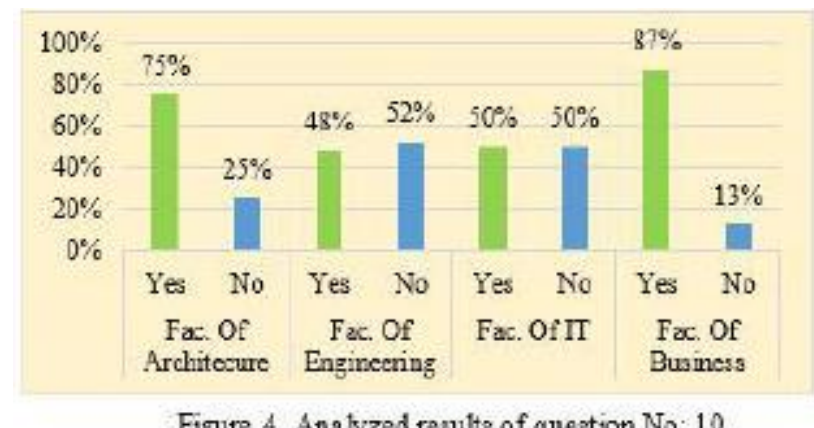

The analyzed results of eleventh question is given in Table 03. Sidropoulos has described through his research that people interpret sustainability through their own value lens therefore, before integrating concepts of sustainability towards tertiary education it is crucial to review individual perceptions both at empirical and theoretical levels [39]. With the results of the analyzed data it is evident that despite the faculty, majority of the lecturers have positive perceptions on ESD at higher education and they have identified the importance of embedding sustainability concepts in teaching curricular. Therefore, the necessary authorities should pay more concern towards allocating resources necessary for these activities. Because even a single course can encourage more active learning towards sustainability at current societal context and provide positively changing students perceptions of sustainability [5].

Table 3. Results of the eleventh question

\begin{tabular}{lccccc}
\hline \multirow{2}{*}{ Faculty } & \multicolumn{5}{c}{ Percentage of integration at different educational Levels } \\
\cline { 2 - 6 } & Strongly Agree & Agree & Neutral & Disagree & Strongly Disagree \\
\hline Architecture & $50 \%$ & $37,5 \%$ & $12,5 \%$ & $12,5 \%$ & $0 \%$ \\
Engineering & $44 \%$ & $28 \%$ & $20 \%$ & $20 \%$ & $4 \%$ \\
Business & $50 \%$ & $25 \%$ & $12,5 \%$ & $12,5 \%$ & $12,5 \%$ \\
IT & $25 \%$ & $62,5 \%$ & $12,5 \%$ & $12,5 \%$ & $0 \%$ \\
\hline
\end{tabular}

Descriptive answers were obtained for the final question of the questionnaire survey. These descriptive answers were categorized on basis of faculty and under the three major requirements; information, knowledge and technology. The analyzed results are given in Table 04. According to the results, majority of the respondents request for the knowledge of sustainability. They have mentioned these requirements depending on their subject areas. Majority of the respondents have beset on themes such as climate change, energy cycles and consumer behavior which are of timely topics with regard to sustainability. Similarly, in the sense of technology, they have identified the requirement of energy efficient technologies to move towards sustainability because there are less of energy efficient technologies in Sri Lankan context. However, when considering the overall requirements that have been mentioned they come from different aspects and in vivid contexts. The existence of various contexts are important to acquire and 
implement competencies related for sustainability. Universities can create space for informal learning towards developing competencies hence it is controllable up to a definite level [40]. Similarly, above identified requirements are important to uplift competencies towards sustainability. Nevertheless, it is most significant that these requirements are more or less fulfilled and at the same time they are achievable. The needs of the present and future generations should be better understood and addressed for universities to become sustainability leaders and change agents. Then the professionals who are well aware in sustainable development can share knowledge with students of all ages and make the transition [10]. University curricula programs have the ability to integrate eco- knowledge and skills across a variety of subjects to increase student's pro environmental intentions [11]. Similarly, through education, research and or outreach universities can foster innovative ideas for sustainability. By facilitating new approaches they can contribute to the changes required towards sustainable development. These approaches and ideas must both theoretical as well as practical to get the maximum benefits in order to integrate sustainability thorough out the world [10].

Table 4. Analyzed results of Question 12

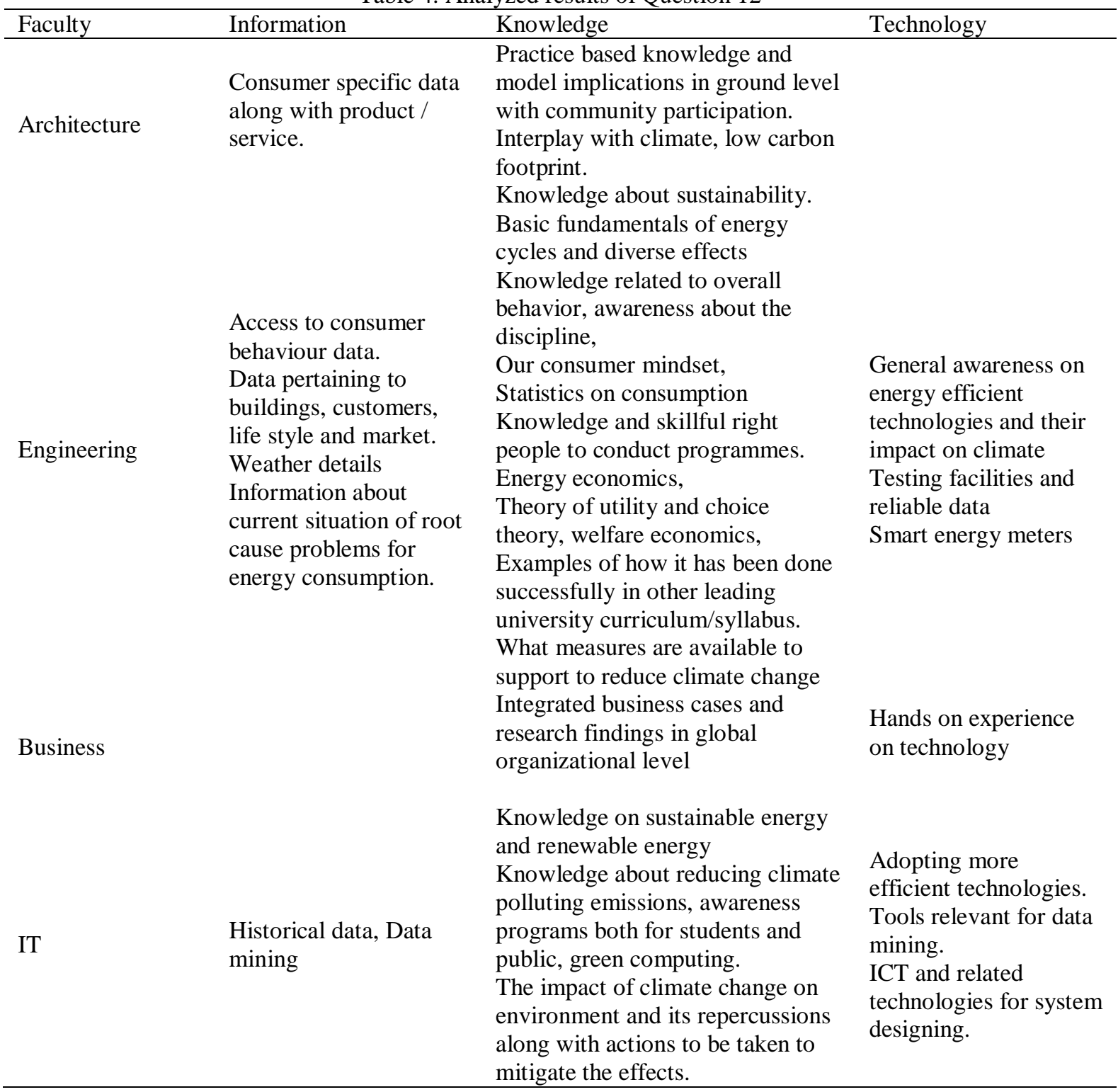

\section{CONCLUSION}

Current study was conducted to explore the barriers existing for ESD in university education in Sri Lanka, to determine the perception of university lecturers on integrating concepts of sustainability into university curricular system and to identify the extent to which lecturers have incorporated concepts of 
sustainability in their teaching modules. According to the results of the study, out of total respondents, $46.93 \%$ have already integrated sustainability concepts in their teaching curricular. They have integrated these concepts not only in bachelor's level, but also in postgraduate levels. Regardless the faculty, all most all respondents have prominently understood the importance of incorporating sustainability concepts in the higher education system and they have a positive perception on integrating sustainability concepts in university teaching curricular. Similarly, with the results it was revealed that $59.18 \%$ of the respondents are willing to integrate sustainability concepts in their teaching curricular in near future. This can be considered as significant initiative for the ESD in university education system in Sri Lankan context. When considering the major barriers existing for ESD in higher education in Sri Lanka, more than of $80 \%$ of respondents were felt that curriculum should reform according to the countries' need and the training opportunities should promote and provide for youth to enhance their practical knowledge. In addition, more than $60 \%$ of respondents were felt that knowledge and skills on ICT should be developed and adequate human recourses should be provide prior to developing the sustainability concepts in curricular. According to the respondent's perception, the requirements identified for incorporating sustainability concepts are more or less similar, regardless of their faculties. Majority of them have identified the need of the fundamental knowledge on thematic areas such as climate change, energy cycles and consumer behavior. Most of them have recognized energy efficient technologies as a major technological requirement towards sustainability. Identifying these requirements and working towards to uplift these requirements would be essential for the success of future sustainable projects. Proper methodologies and work plans need to be established to fulfill these requirements and to overcome the barriers pertaining for ESD in university education system in Sri Lanka. Future researching should be done to overcome the implications and negative consequences prevailing towards integrating sustainability concepts with higher education.

\section{ACKNOWLADGEMENT}

This project has been funded with support from the European Commission. This publication reflects the views only of the author, and the Commission cannot be held responsible for any use which may be made of the information contained therein.

\section{REFERENCES}

[1] UN, "United Nations Conference on Environment and Development-AGENDA 21," 1992, no. June.

[2] T. Shelley, Learning for the future,United Nations Economic Commission for Europe Strategy for Education for Sustainable Development, vol. 26, no. 12. 2006.

[3] O. Url and E. Uri, "Vare, Paul ORCID : 0000 - 0003 - 3182 - 9105 and Scott , William ( 2007 ) Learning for a Change : Exploring the Relationship Between Education and Sustainable Development. Journal of Education for Sustainable," vol. 1, 2007.

[4] UN, Shaping the Future We Want. 2014.

[5] I. R. Abubakar, F. S. Al-shihri, and S. M. Ahmed, "Students ' Assessment of Campus Sustainability at the University of Dammam, Saudi Arabia," 2016.

[6] M. Nejati and M. Nejati, "Assessment of sustainable university factors from the perspective of university students," J. Clean. Prod., vol. 48, pp. 101-107, 2013.

[7] G. Tuncer, "International Research in Geographical and Environmental Education University Students â€TM Perception on Sustainable Development: A Case Study from Turkey University Students' Perception on Sustainable Development : A Case Study from Turkey,” no. June 2013, pp. 37-41, 2008.

[8] R. Drayson, E. Bone, J. Agombar, and S. Kemp, "Student attitudes towards and skills for sustainable development," no. November, 2014.

[9] T. Berglund, N. Gericke, and S. C. Rundgren, "Research in Science \& Technological Education The implementation of education for sustainable development in Sweden : investigating the sustainability consciousness among upper secondary students," no. February 2015, pp. 37-41, 2014.

[10] R. Lozano, F. J. Lozano, K. Mulder, D. Huisingh, and T. Waas, "Advancing Higher Education for Sustainable Development : international insights and critical re fl ections," vol. 48, pp. 3-9, 2013.

[11] F. R. Figueredo and Y. Tsarenko, "Is ' being green' a determinant of participation in university sustainability initiatives ?," 2013.

[12] M. Katherine, R. Lozano, C. Noyes, and M. Rodgers, "Assessing curricula contribution to sustainability more holistically: Experiences from the integration of curricula assessment and students' perceptions at the Georgia Institute of Technology,” J. Clean. Prod., vol. 61, pp. 106-116, 2013.

[13] Y.-C. J. Wu and J.-P. Shen, "Higher education for sustainable development: a systematic review," 2015. 
[14] E. Chuvieco, M. Burgui-Burgui, E. V. Da Silva, K. Hussein, and K. Alkaabi, "Factors affecting environmental sustainability habits of university students: Intercomparison analysis in three countries (Spain, Brazil and UAE), J. Clean. Prod., vol. 198, pp. 1372-1380, 2018

[15] M. Heyl, E. M. Díaz, and L. Cifuentes, "Environmental attitudes and behaviors of college students: a case study conducted at a chilean university," Rev. Latinoam. Psicol., vol. 45, no. 3, p. 487, 2014.

[16] A. R. Bielefeldt, "Incorporating a Sustainability Module into First-Year Courses for Civil and Environmental Engineering Students," no. April, pp. 78-85, 2011.

[17] G. Davis, "The role of case studies for integrating sustainable development into the education of engineers," World Trans. Eng. Technol. Educ., vol. 5, no. 1, pp. 159-162, 2006.

[18] P. Jones, C. J. Trier, and J. P. Richards, "Embedding Education for Sustainable Development in higher education : A case study examining common challenges and opportunities for undergraduate programmes," vol. 47, no. 2008, pp. 341-350, 2014.

[19] E. Bakaç, "Engineering Faculty Students' Perceptions on Climate Change," Environ. Ecol. Res., vol. 6, no. 4, pp. 240-247, 2018.

[20] R. M. Brito, C. Rodríguez, J. L. Aparicio, J. Paolacci, M. L. Sampedro, and J. Beltrán, "Indicators of sustainability in educational practice: Perception of teachers and students of UAGro-Mexico," Sustain., vol. 10, no. 10, 2018.

[21] P. G. Watkins and J. Richters, “'I'm telling you ... the language barrier is the most, the biggest challenge':

[22] Barriers to education among Karen refugee women in,” vol. 56, no. 2, pp. 126-141, 2012.

[23] C. P. Akpan, "Lecturers' perception of the Role of ICT in the Management of University Education for Sustainable Development in Nigeria," Niger. J. Educ. Adm. Plan., vol. 8, no. 1, pp. 113-127, 2008.

[24] G. E. Kiangi, "Computer education and human capacity building for Information Technology in Namibia," Capacit. Build. IT Educ. Dev. Ctries., pp. 39-47, 1998.

[25] G. Ssekakubo, H. Suleman, and G. Marsden, "Issues of Adoption: Have E-Learning Management Systems Fulfilled their Potential in Developing Countries ?," 2011.

[26] T. A. Drape, R. Rudd, M. Lopez, and D. Radford, "Challenges and Solutions to Higher Education Institutions in Africa," Int. J. Educ., vol. 8, no. 1, p. 43, 2016.

[27] Department of census and statistics, "ECONOMIC STATISTICS OF SRI LANKA," 2018.

[28] S. L. Ministry of education, "Education First Sri Lanka," 2013.

[29] S. L. Universrity Grants Commission, "University education in Sri Lanka," 2018.

[30] University Grants Commission, "University Admission in Sri Lanka," 2018.

[31] University Grants Commission, "Graduate Output, Sri Lanka," 2018.

[32] Youth policy Sri Lanka, "Components of Population Change, 2011-2017,” 2017.

[33] University of Moratuwa, "Overview of the University," 2019. [Online]. Available: https://www.mrt.ac.lk/web/. [Accessed: 27-Aug-2019].

[34] D. Y. R. Dr. Y. Rajasekhar, "The Role of Information and Communication Technologies (ICTs) in Higher Education,” Int. J. Sci. Res., vol. 3, no. 3, pp. 83-85, 2012.

[35] R. M. Gnanawasa and S. Lanka, "a Study of a Few Recognized Educational," 2017.

[36] P. Ekins and S. Simon, "Estimating sustainability gaps : methods and preliminary applications for the UK and the," vol. 8009, no. 0, 2001.

[37] K. W. Charu, "Journal of Professional Issues in Engineering Education and Practice, ASCE," vol. 133, no. 3, pp. 188-191, 2007.

[38] J. Fisher and I. Bonn, "Business sustainability and undergraduate management education : an Australian study," pp. 563-571, 2011.

[39] M. Petrini and M. Pozzebon, "Journal of Strategic Information Systems Managing sustainability with the support of business intelligence: Integrating socio-environmental indicators and organisational context," J. Strateg. Inf. Syst., vol. 18, no. 4, pp. 178-191, 2009.

[40] E. Sidiropoulos, "Education for sustainability in business education programs : a question of value," J. Clean. Prod., vol. 85 , pp. 472-487, 2014.

[41] M. R. and U. S. Matthias Barth, Jasmin Godemann, "Developing key competencies for sustainable development in higher education,” Int. J. Sustain. High. Educ., 2010. 